\title{
Expression of cytokeratin in the epithelium of dentigerous cysts and odontogenic keratocysts: an aid to diagnosis
}

\author{
A W MACDONALD, A FLETCHER \\ From the Department of Pathology, University of Leeds, and the Department of Histopathology, Leicester \\ Royal Infirmary
}

SUMMARY Sections of tissue embedded in paraffin wax from 18 selected odontogenic cysts were studied both histologically and immunohistochemically with antibodies to cytokeratins using the indirect peroxidase technique. The cysts were divided on a clinical and histological basis into two equal groups comprising dentigerous cysts and odontogenic keratocysts. It was possible to differentiate the two cyst types in every case by the pattern of staining using the monoclonal antibody LP34 for cytokeratins of intermediate molecular weight. The monoclonal antibody CAM $5 \cdot 2$ for cytokeratins of low molecular weight was not discriminatory. Such a clear distinction may prove useful diagnostically in distinguishing between two cysts of similar appearance but very different behaviour.

Dentigerous cysts and odontogenic keratocysts are both thought to arise from the odontogenic epithelium-the former arising from the enamel organ usually after the crown of the tooth has formed, the latter from the dental lamina or primordial odontogenic epithelium. Consequently odontogenic keratocysts are often associated with a site where there is absence of a tooth from the series. Despite having a similar odontogenic origin clinical behaviour differs, particularly the rate of recurrence. A dentigerous cyst should not recur after adequate excision and may even be treated by marsupialisation. The keratocyst, however, has a strong tendency to recur, the rate of recurrence being as high as $60 \% .^{1-3}$

Ideally, the diagnosis is best made preoperatively so that the surgical procedure can be tailored accordingly. Clinical and radiological assessment is obviously of considerable importance but may sometimes be quite misleading. ${ }^{4}$

Consequently, much work has centred on the odontogenic keratocysts in an attempt to find a reliable marker. Soluble protein estimation, if below $48 \mathrm{~g} / \mathrm{l}$, would tend to indicate a keratocyst. ${ }^{5}$ More recent work has centred on the qualitative assessment of "specific" cyst contents ${ }^{67}$; these techniques, useful as they may be, do not, however, replace histological examination of the cyst after excision, which is still required for definitive diagnosis.

Accepted for publication 2 February 1989
Both cyst types are lined by a stratified squamous epithelium. Subtle differences may be seen on routine examination of slides stained with haematoxylin and eosin which may enable those with experience to distinguish these cysts, but misinterpretation can easily occur. A further diagnostic aid would be useful.

\section{Material and methods}

Eighteen odontogenic cysts were selected from the files of the Leicester Royal Infirmary between 1981 and 1987. Inflammatory cysts such as radicular and residual cysts were excluded from the study along with any other cyst showing a high degree of inflammation. Initial diagnosis was made according to the criteria shown in table 1 , which includes clinical, radiological, and histological variables, based on the WHO histological typing of odontogenic cysts. ${ }^{8}$

Sections were cut from the original blocks, rehydrated, and treated with $0.1 \%$ trypsin in $0.12 \%$ calcium chloride, adjusted to $\mathrm{pH} 7 \cdot 8$, at $37^{\circ} \mathrm{C}$ for 20 minutes. Endogenous peroxidase activity was blocked using $\mathrm{H}_{2} \mathrm{O}_{2}$ in methanol for 30 minutes. The sections were washed in water and phosphate buffered saline (PBS) before being treated with a 1/20 dilution of normal rabbit serum for 10 minutes.

The sections were then drained and treated with the antisera at appropriate dilution (LP 34 (CKI, Dakopatts) $1 / 200$, CAM 5.2 (Buton Dickenson) $1 / 25$ ) and incubated overnight at room temperature. After wash- 


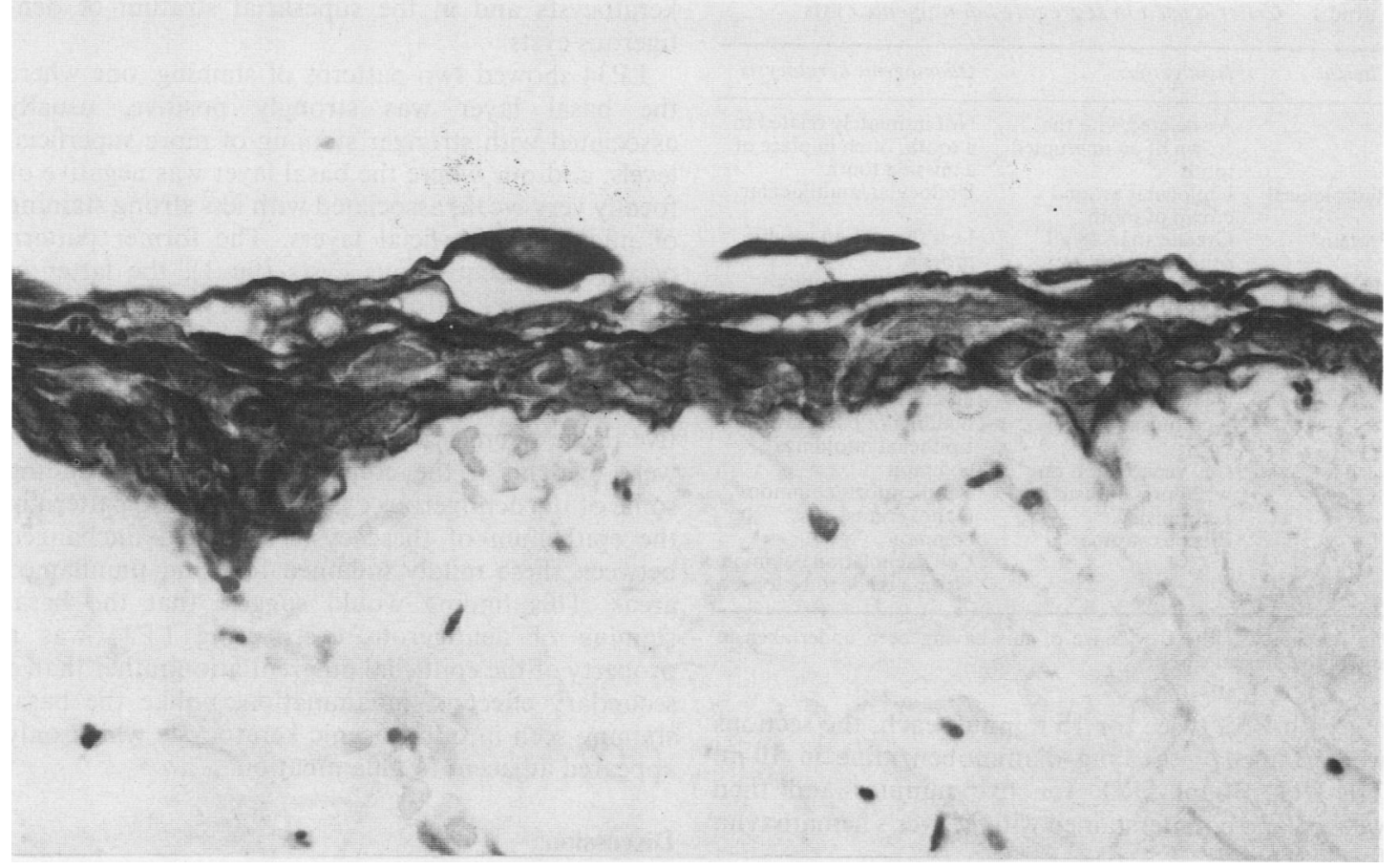

Fig 1 LP34 staining of epithelium of an uninflamed dentigerous cyst showing full thickness staining.

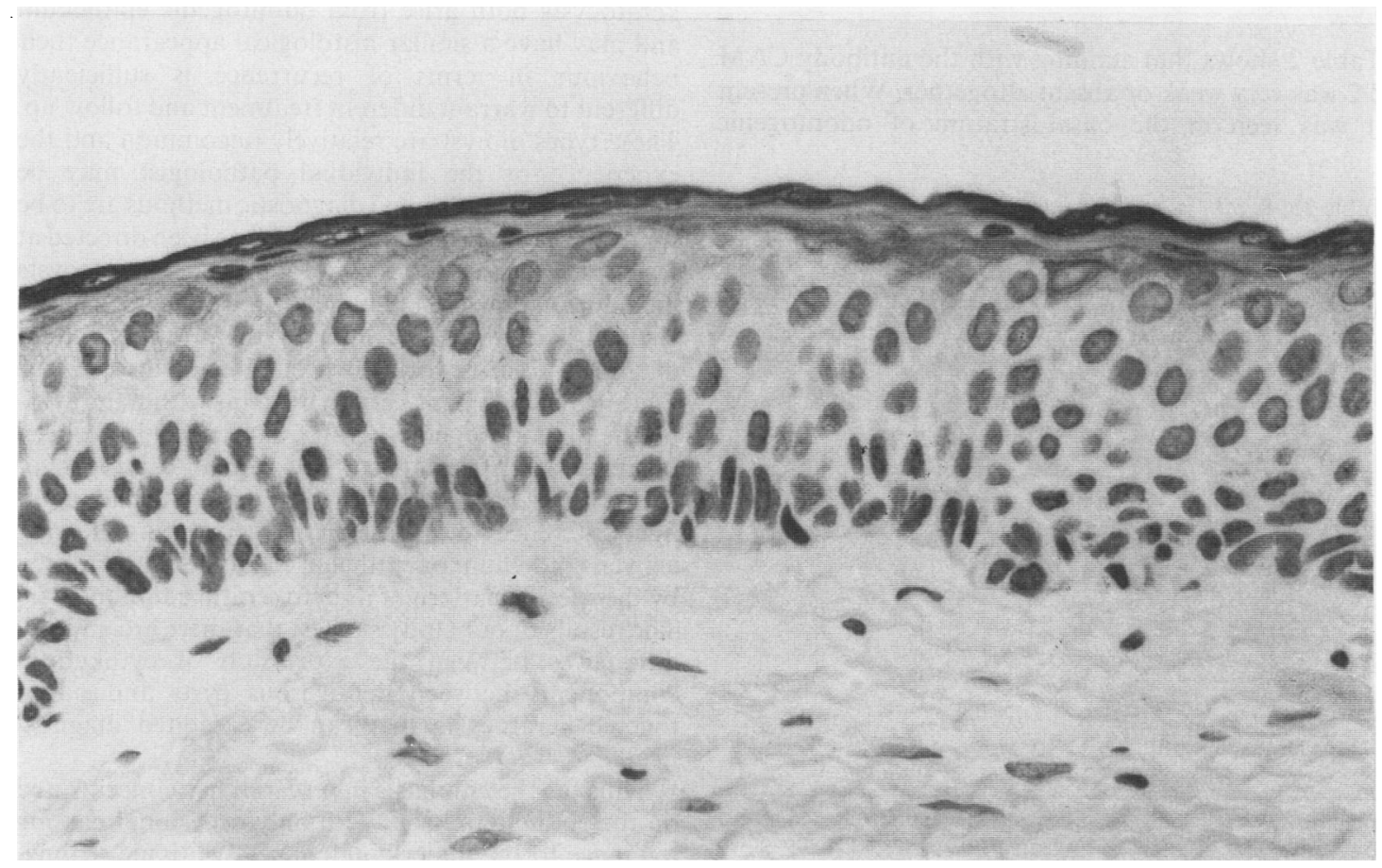

Fig 2 LP34 staining of epithelium of an uninflamed odontogenic keratocyst showing absence of staining of the basal layer. 
Table 1 Criteria used to segregate odontogenic cysts

\begin{tabular}{|c|c|c|}
\hline Clinical & Dentigerous & Odontogenic keratocysts \\
\hline Radiological & $\begin{array}{l}\text { Associated with the } \\
\text { crown of an unerupted } \\
\text { tooth } \\
\text { Unilocular around }\end{array}$ & $\begin{array}{l}\text { Not intimately related to } \\
\text { a tooth, often in place of } \\
\text { a missing tooth } \\
\text { Unilocular/multilocular }\end{array}$ \\
\hline & $\begin{array}{l}\text { crown or tootn } \\
\text { Greater than } 48 \mathrm{~g} / 1 \\
\text { soluble protein }\end{array}$ & $\begin{array}{l}\text { Less than } 48 \mathrm{~g} / 1 \text { soluble } \\
\text { protein }\end{array}$ \\
\hline Histology & $\begin{array}{l}\text { Stratified squamous } \\
\text { epithelium three to four } \\
\text { cells thick } \\
\text { No basal palisading } \\
\text { May be mucous cells or } \\
\text { ciliated cells } \\
\text { Keratinisation may } \\
\text { occur } \\
\text { Cell vacuolation rare } \\
\text { when present usually } \\
\text { keratinising } \\
\text { Fibrous stroma }\end{array}$ & $\begin{array}{l}\text { Stratified squamous } \\
\text { epithelium } \\
\text { Prominent basal } \\
\text { palisading } \\
\text { Rete ridges generally } \\
\text { absent but occasional } \\
\text { budding of basal layers } \\
\text { Epithelial infoldings } \\
\text { common } \\
\text { Parakeratosis common, } \\
\text { orthokeratosis less } \\
\text { common } \\
\text { Cell vacuolation common } \\
\text { Stroma tends to be loose }\end{array}$ \\
\hline
\end{tabular}

*In no case was there evidence of this having been undertaken in any of the present cases.

ing with PBS twice for 15 minutes each, the sections were stained with $5 \mathrm{mg}$ diaminobenzidine in $10 \mathrm{ml}$ Tris- $\mathrm{HCl}, 10 \mathrm{ml} \mathrm{H}_{2} \mathrm{O}_{2}$ for five minutes and then washed and counterstained with Mayer's hematoxylin for 90 seconds.

\section{Results}

Table 2 shows that staining with the antibody CAM 5.2 was very weak or absent altogether. When present it was seen in the basal stratum of odontogenic

Table 2 Results of staining intensity

\begin{tabular}{|c|c|c|c|c|c|c|}
\hline \multirow{2}{*}{$\begin{array}{l}\text { Case } \\
\text { No }\end{array}$} & \multirow[b]{2}{*}{ Cyst } & \multicolumn{3}{|l|}{ LP34 } & \multicolumn{2}{|c|}{ CAM $5 \cdot 2$} \\
\hline & & Basal & Mid & Superficial & Basal & Superficial \\
\hline $\begin{array}{r}1 \\
2 \\
3 \\
4 \\
5 \\
6 \\
7 \\
8 \\
9 \\
10 \\
11 \\
12 \\
13 \\
14 \\
15 \\
16\end{array}$ & $\begin{array}{l}\text { OKC } \\
\text { OKC } \\
\text { OKC } \\
\text { OKC } \\
\text { OKC } \\
\text { OKC } \\
\text { OKC } \\
\text { OKC } \\
\text { OKC } \\
\text { Dent. } \\
\text { Dent. } \\
\text { Dent. } \\
\text { Dent. } \\
\text { Dent. } \\
\text { Dent. } \\
\text { Dent. }\end{array}$ & $\begin{array}{l}0 \\
0 \\
0 \\
0 \\
0^{*} \\
0 \\
0 \\
0^{*} \\
0 \\
+++ \\
+++ \\
+++ \\
+++ \\
+++ \\
++ \\
+++\end{array}$ & $\begin{array}{l}t \\
+ \\
++ \\
+++ \\
++ \\
+++ \\
++ \\
++ \\
+++ \\
++ \\
+++ \\
+++ \\
+++ \\
+++ \\
+++ \\
+++\end{array}$ & $\begin{array}{l}+++ \\
+ \\
+++ \\
+++ \\
+++ \\
+++ \\
+++ \\
+++ \\
+++ \\
+++ \\
+++ \\
+++ \\
+++ \\
+++ \\
+++ \\
+++\end{array}$ & $\begin{array}{l}+/- \\
0 \\
+/- \\
0 \\
0 \\
0 \\
0 \\
+/- \\
+/- \\
0 \\
0 \\
0 \\
0 \\
0 \\
0 \\
0\end{array}$ & $\begin{array}{l}0 \\
0 \\
0 \\
0 \\
0 \\
0 \\
0 \\
0 \\
0 \\
+/- \\
+/- \\
0 \\
0 \\
0 \\
+ \text { patchy } \\
0\end{array}$ \\
\hline $\begin{array}{l}17 \\
18\end{array}$ & $\begin{array}{l}\text { Dent. } \\
\text { Dent. }\end{array}$ & $\begin{array}{l}+++ \\
++t\end{array}$ & $\begin{array}{l}+++ \\
++t\end{array}$ & $\begin{array}{l}+++ \\
++t\end{array}$ & $\begin{array}{l}0 \\
0\end{array}$ & $0^{+1-}$ \\
\hline
\end{tabular}

The intensity of staining was assessed semiquantatively and scored as below: $0=$ None; $\quad+=$ weak; $++=$ moderate; $+++=$ strong.

$0^{*}=$ generally no staining but weak. keratocysts and in the superficial stratum of dentigerous cysts.

LP34 showed two patterns of staining, one where the basal layer was strongly positive, usually associated with stronger staining of more superficial levels, and one where the basal layer was negative or focally very weak, associated with less strong staining of mid and superficial layers. The former pattern occurred in dentigerous cysts (fig 1); the latter in ondontogenic keratocysts (fig 2). Two odontogenic keratocysts showed weak focal staining (case 5 and case 8) in areas which were directly adjacent to chronic inflammatory cellular infiltration within the connective tissue stroma. Similar foci of mild inflammation were evident in the connective tissue surrounding some of the dentigerous cysts. The staining pattern in the epithelium of these cysts remained unchanged between these mildly inflamed foci and uninflamed areas. This finding would suggest that the basal staining of dentigerous cysts using LP34 was a property of the epithelial differentiation rather than a secondary effect of inflammation, unlike the basal staining seen in odontogenic keratocysts which only appeared adjacent to inflammation.

\section{Discussion}

Although dentigerous cysts and odontogenic keratocysts both arise from odontogenic epithelium and may have a similar histological appearance their behaviour in terms of recurrence is sufficiently different to warrant different treatment and follow up. These types of cyst are relatively uncommon and the experience of the individual pathologist may be limited, so any additional diagnostic methods are to be welcomed. Much current research has been directed at features specific to the odontogenic keratocysts including keratocyst antigen' and enzyme histochemistry of the epithelium ${ }^{10-12}$ in an effort to aid diagnosis. Recent work has been directed towards the intermediate filament keratin proteins within the cytoplasm of odontogenic keratocysts which have been identified and catalogued. ${ }^{13} \mathrm{~A}$ similar catalogue of cytokeratins from other odontogenic cysts may highlight differences in expression of cytokeratins allowing a given epithelium or epithelial cell to be characterised by the specific pattern of its cytokeratin components. ${ }^{14}$ The results of our study suggest that there are, indeed, differences between the expression of cytokeratin components between dentigerous cysts and odontogenic keratocysts that can be exploited diagnostically.

Thus far the emphasis in research has concentrated on the epithelium itself, with only occasional passing reference to the underlying connective tissue stroma. One feature among the histological differences bet- 
ween dentigerous cysts and odontogenic keratocysts that has been cited many times is the stroma, which in the case of the latter is described as delicate, loose, and rich in mucopolysaccharide. The interaction between an epithelium and its stroma is complex and not well understood, but observations from this study show that focal inflammation within the stroma of odontogenic keratocysts affects the local expression of cytokeratins. This observation, in addition to other observations that odontogenic keratocyst epithelium, when transplanted into nude mice, only retains its typical appearance histologically if supported by its own connective tissue stroma, ${ }^{15}$ suggest that the differentiation of the epithelium is not independent of the stroma.

The results of this study show that odontogenic keratocysts and dentigerous cysts, in the absence of clinically important inflammation, may be reliably distinguished on the basis of staining of the basal layer of the cyst lining using the commonly available monoclonal antibody LP34. Similarly, the technique described may have limitations in distinguishing between cysts in which there is considerable inflammatory change, a situation where histological distinction is particularly difficult.

We thank Mr R Cullen and staff of the special histology laboratory, Leicester Royal Infirmary for their kind assistance and Mrs Lynne Bailey for typing the manuscript.

\section{References}

1 Vedtofte P, Praetorius F. Recurrence of the odontogenic keratocyst in relation to clinical and histological features. Int J Oral Surg 1979;8:412-20.

2 Ahlfors E, Larsson A, Sjogen S. The odontogenic keratocyst: a benign cystic tumour? J Oral Maxillofac Surg 1984;42:10-9.

3 Zachariades N, Papanicolaou S, Triantafyllou D. Odontogenic kertatocysts: review of the literature and report of sixteen cases. J Oral Maxillofac Surg 1985;43:177-82.

4 Soskolne WA, Shear M. Observations on the pathogenesis of primordial cysts. Br Dent J 1967;123:321-6.

5 Kramer IRH, Toller PA. The use of exfoliative cytology and protein estimations in pre-operative diagnosis of odontogenic keratocysts. Int J Oral Surg 1973;2:143-51.

6 Kunsela P, Hormia M, Trompo H, Ylipaavalniemi P. Demonstration and partial characterisation of a novel soluble antigen present in keratocysts. Oncodev Biol Med 1982;3:383-90.

7 Kunsela P, Ylipaavalniemi P, Thesleff I. The relationship between the keratocyst antigen (KCA) and keratin. J Oral Pathol 1986;15:287-91.

8 Pindberg JJ, Kramer IRH, Torloni H. Histological typing of ondotogenic tumours, jaw cysts and allied lesions. International Histological Classification of Tumours. No 5 Geneva: WHO 1971.

9 Douglas CWI, Craig GT. Recognition of protein apparently specific to odontogenic keratocyst fluids. J Clin Pathol 1986;39:1108-15.

10 Kobayasi T, Hansen J. Ultrastuctural studies of odontogenic cysts III. Acid phosphatases. Acta Morphol Neerl Scand 1970;8: 63-78.

11 Magnusson BC. Odontogenic keratocysts: a clinical and histological study with special reference to enzyme histochemistry. J Oral Pathol 1978;7:8-18.

12 Stenman G, Magnusson B, Lennartsson B, Juber-Ode M. In vitro growth characteristics of human odontogenic keratocysts and dentigerous cysts. J Oral Pathol 1986;15:143-5.

13 Shuler CF, Schiver BJ. Identification of intermediate filament keratin proteins in parakeratinised odontogenic keratocysts. Oral Surg Oral Med Oral Pathol 1987;64:439-44.

14 Moll R, Franke WW, Schiller DL, Geiger B, Krepler R. The catalogue of human cytokeratins: patterns of expression in normal epithelium, tumours and cultured cells. Cell 1982;31: 11-24.

15 Vedtofte OP, Holmstrup P, Dabelsteen E. Human odontogenic keratocyst transplants in nude mice. Scand $J$ Dent Res 1982;90:306-14.

Requests for reprints to: Dr A W MacDonald, Department of Pathology, University of Leeds, Leeds LS2 9JT, England. 